\title{
Kauran kuorinnalla laaturehua ilman säilyvyysongelmia
}

\author{
Pirjo Peltonen-Sainio ${ }^{1)}$, Markku Kontturi ${ }^{1)}$, Pekka Lehtinen ${ }^{2)}$, Ari Rajala ${ }^{1)}$ ja Anna-Maija Kirkkari ${ }^{3)}$ \\ ${ }^{1)}$ MTT Maa- ja elintarviketalouden tutkimuskeskus, Kasvintuotannon tutkimus, 31600 Jokioinen, \\ etunimi.sukunimi@mtt.fi \\ ${ }^{2)}$ Tekninen korkeakoulu, Biokemian ja mikrobiologian latoratorio, PL 6100, 02015 TKK, \\ pekka.lehtinen@hut.fi \\ 3)Työtehoseura ry., PL 13, 05201 Rajamäki, anna-maija.kirkkari@tts.fi
}

\section{Johdanto}

Kauran jyvä koostuu kahdesta hyvin erilaisesta komponentista, ravitsemuksellisesti arvokkaasta jyväytimestä sekä sitä ympäröivästä, laadultaan olkea muistuttavasta kuoresta, jonka muodostavat ulko- ja sisähelve. Tämä kuoreksi kutsuttu, runsaasti huonosti sulavaa kuitua sisältävä suojarakennelma on tärkein yksittäinen kauran laatua ja käyttökelpoisuutta heikentävä tekijä (Salo ja Kotilainen 1970). Se on myös keskeisin syy, miksi kaura on monin paikoin korvattu muilla rehuviljoilla.

Kauran kuoripitoisuutta on pyritty tietoisesti alentamaan kasvinjalostuksella. Tästä äärimmäisin esimerkki on paljasjyväinen kaura, jonka ohuet, paperimaiset, vähäligniiniset helpeet irtoavat puitaessa jyväytimen ympäriltä (Ougham ym. 1996). Sama tai jopa huomattavasti parempi tulos voidaan saavuttaa myös kuorimalla tavanomainen kaura ennen kotieläimille syöttämistä. Kuorinnassa tulee huomioida, että mahdollisimman suuri osa ravitsemuksellisesti arvokkaista jyväytimistä saadaan ehjinä talteen.

Maa- ja metsätalousministeriön rahoittamassa hankkeessa tutkimme kuorittavan jyvän laadun ja kosteuden sekä erilaisten keskipakokuorijan säätöjen vaikutuksia jyväydinsaantoon ja roskina poistuvaan hävikkiin, jyvien rikkoutumiseen, ravitsemukselliseen laatuun ja laskennalliseen energiapitoisuuteen. Lisäksi tutkittiin jyvien kuorinnan vaikutuksia säilyvyyteen, erityisesti rasvojen hajoamiseen, härskiintymiseen, koska kauran jyvä sisältää runsaasti rasvaa.

\begin{abstract}
Aineisto ja menetelmät
Tutkimus koostui kolmesta eri osakokeesta: 1) Rivakka-keskipakokuorijan (http://www.nipere.fi) säätöjen sekä 2) kuorittavan jyvämateriaalin lähtölaadun ja kosteuspitoisuuden vaikutukset kuoriutuvuuteen, ravitsemukselliseen laatuun, laskennalliseen energiapitoisuuteen sekä jyväytimien rikkoutumiseen ja 3) kuorittujen jyvien säilyvyys, erityisesti rasvojen hapettuminen eri säilytysolosuhteissa. Kuorintakokeet järjestettiin MTT Maa- ja elintarviketalouden tutkimuskeskuksessa Jokioisilla ja säilyvyyskokeet Teknisessä korkeakoulussa, Espoossa. Kokeissa kuorittiin Jokioisilla vuosina 1996-2001 Virallisissa lajikekokeissa viljeltyä Salo-kauraa, jonka lähtölaatu tutkittiin (kuoripitoisuus, jyväpaino, hehtolitran paino, kosteuspitoisuus, proteiini-, rasva-, kuitu- ja tuhkapitoisuus sekä laskennallinen energiapitoisuus).

Rivakka-keskipakokuorijan kuorintatehoon vaikutettiin kierrosnopeutta säätämällä. Tutkittavat kierrosnopeudet olivat 200, 250, 300, 350, 400, 450 ja 500 kierrosta minuutissa. Selvitettäessä jyvän kosteuspitoisuuden vaikutusta kuoriutuvuuteen jyvänäytteisiin imeytettiin eri määriä vettä, jolloin saavutettiin seuraavat kahdeksan kosteusluokkaa: 10.3-10.5\%, 11.4-11.5\%, 12.4-12.5\%, 13.2-13.5\%, 14.1$14.4 \%, 15.4-15.5 \%, 16.3-16.4 \%$ ja 17.3-17.4\%. Eri kierrosnopeuksilla kuorittuja jyväydinnäytteitä sekä kuorimatonta kontrollia varastoitiin 10,20 ja $30{ }^{\circ} \mathrm{C}$ lämpötilassa. Näistä näytteistä määritettiin härskiintymistä ilmentävien vapaiden rasvahappojen osuus sekä haihtuvista yhdisteistä pentanaalin ja heksanaalin pitoisuudet heti kuorinnan jälkeen sekä kahden ja viiden kuukauden kuluttua kuorinnasta.
\end{abstract}

\section{Tulokset ja tulosten tarkastelu}

Kaurasadon jyvistä sitä useampi irtaantui kuoristaan, mitä suurempaa keskipakokuorijan kierrosnopeutta käytettiin (Kuva 1). Kuorintatehon parantuessa ilmeni kuitenkin yhä enemmän jyvien rikkoutumista, jolloin hävikki kasvoi. Kuorittaessa tavanomaista kauraa kotoiseksi rehuksi, ei tarvitse tavoitella täydellistä kuoriutuvuutta vaan tulee löytää kompromissi saatavan sadon laadulle ja hävikille. 350 kierrosta minuutissa osoittautui hyväksi kompromissiksi, sillä tällöin kuoriutumatta jääviä jyviä oli niukasti (alle 10\%) ja saatavan ydinsadon ravitsemuksellinen arvo sekä energiapitoisuus olivat jo huomattavasti parantuneet kuorimattomaan kauraan verrattuna. (Taulukko 1). Lisäksi jyvien rikkoutuminen oli kohtuullista (alle 5 paino-\% ydinsaannosta) kyseistä kierrosnopeutta käytettäessä (Kuva $1)$.

Kuorittavan raaka-aineen laatu vaikutti olennaisesti kuorintatulokseen. Mitä kosteampana jyvät 
kuorittiin, sitä heikommin niiden kuoret irtosivat (Kuva 2). Toisaalta kuorittaessa jyvät kuivina ne rikkoutuivat herkemmin. Havaittiin, että normaaliin varastokosteuteen kuivatut jyvät kuoriutuivat jo kiitettävästi, joten satoa ei tarvitse kuivata normaalia kuivemmaksi hyvän kuorintatuloksen varmistamiseksi. Jyvien kosteus ei ollut kuitenkaan ainoa kuoriutuvuuteen vaikuttava tekijä. Kuorittaessa eri vuosina korjattua satoa, havaittiin Brownen ym. (2002) tapaan myös muita, jyvän kosteuspitoisuudesta riippumattomia eroja. Jyväkoko ei vaikuttanut kuoriutuvuuteen, kuten myös Doehlert ym. (1999) ovat havainneet. Heidän kokeissaan jyväkokojakaumalla ja hehtolitran painolla oli kuitenkin merkitystä kuoriutuvuuteen.

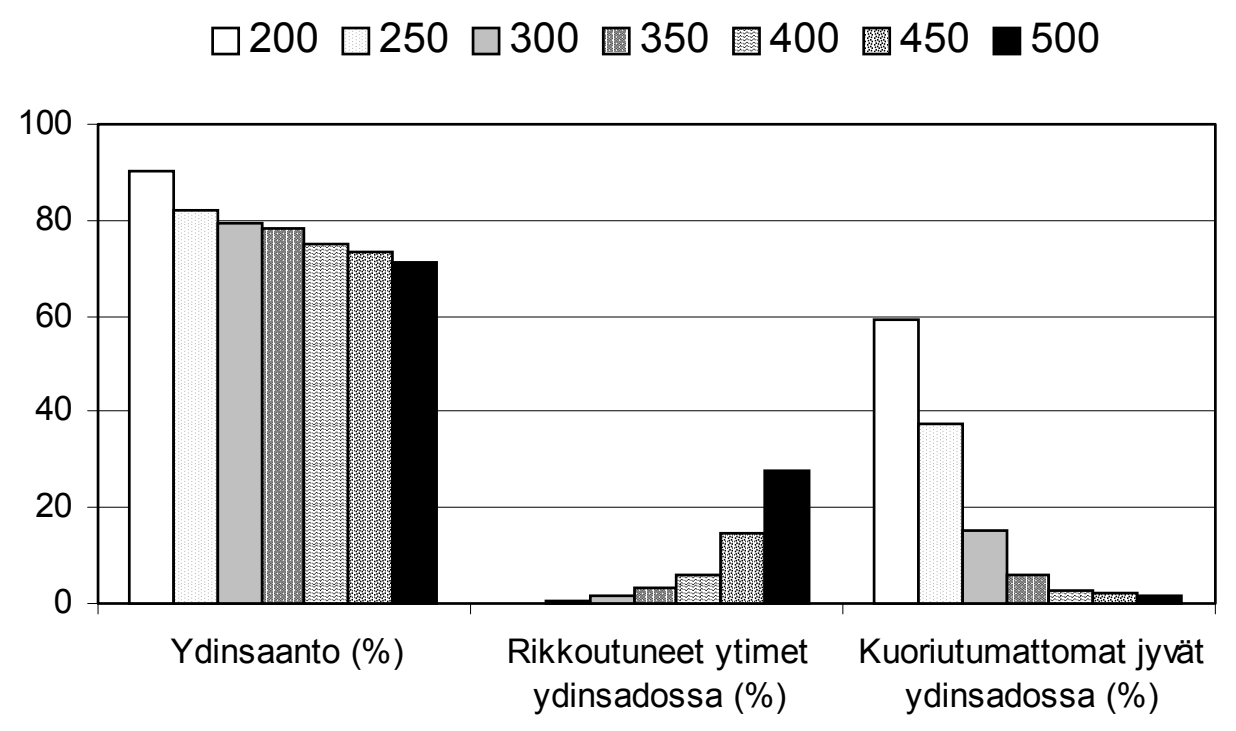

Kuva 1. Kauran jyvien keskipakokuorinnan vaikutus ydinsaantoon sekä rikkoutuneiden ja kuoriutumatta jääneiden jyväydinten osuuteen.

Taulukko 1. Keskipakokuorinnassa käytetyn kierrosnopeuden (kierrosta minuutissa) vaikutus kaurarehun ravitsemukselliseen laatuun ja laskennalliseen energiapitoisuuteen.

\begin{tabular}{lccccccc} 
Laatuominaisuus & 200 & 250 & 300 & 350 & 400 & 450 & 500 \\
\hline Raakaproteiini (\%) & 13.6 & 14.7 & 15.5 & 15.7 & 15.7 & 15.7 & 15.8 \\
Raakarasva (\%) & 5.7 & 6.0 & 6.2 & 6.2 & 6.3 & 6.3 & 6.3 \\
Raakakuitu (\%) & 6.3 & 4.5 & 2.8 & 2.3 & 2.1 & 1.7 & 1.6 \\
ME märehtijä (MJ) & 13.7 & 13.9 & 14.1 & 14.1 & 14.2 & 14.2 & 14.2 \\
NE sika (MJ) & 11.1 & 11.3 & 11.5 & 11.6 & 11.6 & 11.6 & 11.6 \\
ME siipikarja (MJ) & 14.8 & 15.2 & 15.4 & 15.6 & 15.6 & 15.7 & 15.7 \\
\hline
\end{tabular}

Vaikka jyvät rikkoutuivat keskipakokuorinnassa, ei tämä aiheuttanut rasvojen härskiintymistä. Kokeessa käytettiin jopa $30^{\circ} \mathrm{C}$ säilytyslämpötiloja ilman, että merkittävää rasvojen hapettumista olisi havaittu edes pitkään varastoitaessa. Toisaalta korkea jyväkosteus on keskeisin varastoitavuutta heikentävä tekijä, joten jyvien ollessa kokeemme tapaan normaalisti kuivattuja, ei riskiä kuorinnan aiheuttamalle rasvojen härskiintymiselle ilmennyt. Vapaiden rasvahappojen osuus kuitenkin lisääntyi hivenen jyvien rikkoutumisen yleistyessä korkeilla kierrosnopeuksilla kuorittaessa. Pitoisuudet olivat kuitenkin enimmilläänkin niin alhaisia, etteivät ne aiheuttane esimerkiksi makuvirheitä. Tutkimustulokset tullaan esittämään yksityiskohtineen julkaisuissa Peltonen-Sainio ym. (2004a, 2004b). 


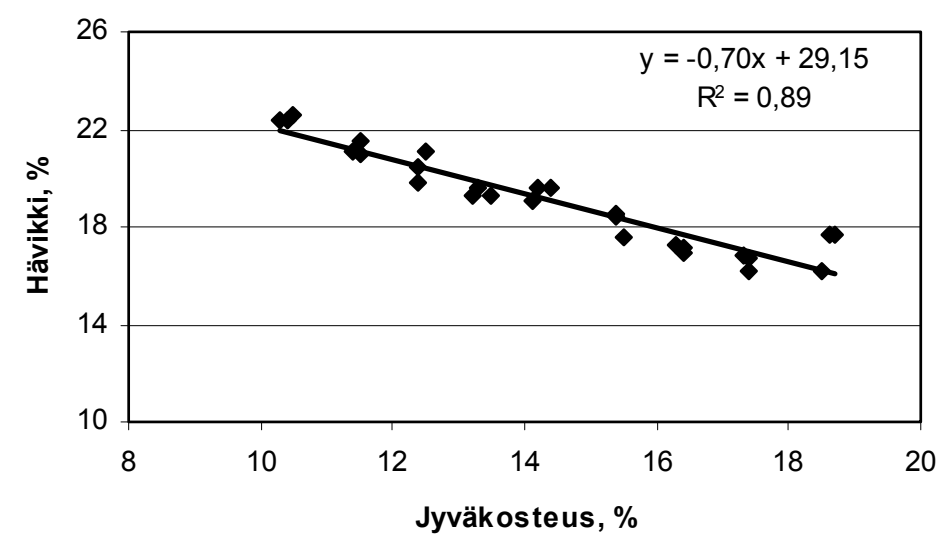

Kuva 2. Mitä kosteampana jyvämateriaali kuoritaan, sitä huonommin kuoret irtoavat, jolloin hävikin muodostavien roskien osuus jää alhaiseksi, mutta saantona saatava ydinsato on ravitsemukselliselta laadultaan heikompaa. Kokeessa käytetty kierrosnopeutena $350 \mathrm{r} / \mathrm{min}$.

\section{Johtopäätökset}

Kauran keskipakokuorinta paransi olennaisesti kauran ravinto- ja energiapitoisuutta tarjoten vaihtoehdon paljasjyväisen kauran viljelylle. Kohtuullista kierrosnopeutta (350 kierrosta minuutissa) käytettäessä saadaan rehulaatua parannettua merkittävästi ilman huomattavia kuorinnan aiheuttamia hävikkejä. Vaikka keskipakokuorija rikkoi jyviä erityisesti käytettäessä korkeita kierrosnopeuksia, ei kuoritun materiaalin varastoitavuus kärsinyt, koska kuorinta ei aiheuttanut rasvojen hapettumista eli härskiintymistä. Tämä viitannee siihen, että viljelijät voivat halutessaan kuoria tai tilata kuorinnan suurina erinä ilman säilyvyysongelmia.

\section{Kirjallisuus}

Browne, R.A., White, E.M. \& Burke, J.I. 2002. Hullability of oat varieties and its determination using a laboratory dehuller. J. Agric. Sci 138: 185-191.

Doehlert, D.C., McMullen, M.S. \& Baumann, R.R. 1999. Factors affecting groat percentage in oat. Crop Sci. 39: 1858-1865.

Ougham, H.J., Lapitova, G. \& Valentine, J. 1996. Morphological and biochemical characterization of spikelet development in naked oat (Avena sativa). New Phytologist 134: 5-12.

Peltonen-Sainio, P., Kontturi, M., Rajala, A. \& Kirkkari, A.-M. 2004. Impact dehulling oat grain to improve quality of on-farm produced feed. I Hullability and associated changes in nutritive value and energy content. Agric. Food Sci. Finl. 13, tarjottuna julkaistavaksi.

Peltonen-Sainio, P., Lehtinen, P., Kontturi, M., Rajala, A. \& Kirkkari, A.-M. 2004. Impact dehulling oat grain to improve quality of on-farm produced feed. II Groat breakage and storability. Agric. Food Sci. Finl. 13, tarjottuna julkaistavaksi.

Salo, M.-L. \& Kotilainen, K. 1970. On the carbohydrate composition and nutritive value of some cereals. J. Sci. Agric. Soc. Finl. 42: 21-29. 